\title{
PROJECT: "MOBILE LEGAL CLINIC - SERVICE FOR VULNERABLE AND DISADVANTAGED GROUPS" (DECEMBER 2016 - NOVEMBER 2018)
}

\author{
Sanja Tošić, Nikola Božanović
}

Club for Youth Empowerment 018, Niš, Serbia

The Project "Mobile Legal Clinic - service for vulnerable and disadvantaged groups" was implemented by the Club for Youth Empowerment 018 (KOM 018) from Niš in cooperation with the Faculty of Law, University of Nis, and the Association of Roma "Prokuplje" from Prokuplje, in the period from December 2016 to November 2018.

\section{PROJECT GOALS}

The overall goal of the Mobile Legal Clinic (MLC) project was to develop services for protection of human rights and provide free legal assistance to members of vulnerable and deprived social groups in the local communities. Specific objectives of the project were:

- to equip law students with the knowledge, skills and competences to protect and promote human rights, to ensure additional educational opportunities and support their engagement in their local communities,

- to support people from vulnerable groups in exercising their human rights, and

- to contribute to the combat against violation of human rights.

\section{PROJeCT ACTIVITIES}

The Mobile Legal Clinic Project was implemented through different kind of activities:

1. The preparation stage included the following activities: publishing the Call for participation and selection of student-trainees; obtaining approval from the Niš Bar Association; and signing protocols of cooperation.

Call for participation and selection of students who would be trained and who would participate in the mobile legal clinic activities was aimed at law students in the $3^{\text {rd }}$ and $4^{\text {th }}$ year of undergraduate academic law study program. After the call had been published, students submitted their applications and a total of 30 law students were selected to participate in the Project.

Received May $15^{\text {th }}, 2019$ / Accepted July $5^{\text {th }}, 2019$

Corresponding author: Sanja Tošić, president of the Club for Youth Empowerment 018

E-mail: sanjatosic1@hotmail.com; 
Obtaining permission from the Bar Association of Niš was essential in terms of hiring qualified legal practitioners (lawyers) to provide legal assistance to MLC beneficiaries.

Protocols of cooperation: KOM 018 and Faculty of Law signed protocols of cooperation with local organizations and institutions in order to ensure greater outreach in the local communities and provide free legal assistance to a larger number of MLC beneficiaries. Some of the organizations involved were the local Roma organizations working with youth and women, Safe House for the victims of domestic violence, the Social Welfare Center in Niš, Association of Roma "Prokuplje", other Roma NGOs, youth organizations, etc.

Time frame: the first two months of the project (November-December 2016)

2. Mobile Legal Clinic theoretical and practical training for 30 law students: initial Mobile Legal Clinic theoretical and practical training in the first 1st year of the Project.

Time frame: in the $3^{\text {rd }}$ month of the Project (January 2017)

3. Mobile Legal Clinic outreach for 160 - 200 beneficiaries in the local communities: Within the envisaged 20-month period, Mobile Legal Clinic organized monthly visits to organizations/institutions involved in the project (one organization per week). The visits were organized in Nis and Prokuplje. During the visit, each Mobile Legal Clinic team included 4 to 6 students, a Law Faculty professor or teaching assistant, and a legal practitioner (lawyer). This stage of project activity includes a client interview, where two students talk to possible beneficiaries, in the presence of a professor/teaching assistant and a lawyer sitting in a separate room. First, an oral interview is conducted in order to collect the beneficiary's information; then, the beneficiary explains the specific problem and the kind of assistance he-she would like to obtain within the envisaged project activities. After that, students have an obligation to collect all necessary documents related to the case, prepare legal documents that will help beneficiaries to start legal proceedings, and consult with the professor/assistant and the lawyer how to proceed with the case. Once the professor/assistant and the lawyer approve the prepared documents for the case, the beneficiary is invited to take adequate legal documents and submit them to relevant state institutions in the form of private pleadings. It was originally anticipated that the Mobile Legal Clinic services would be used by 8 to 10 beneficiaries per month, meaning that at least 160- 200 beneficiaries from vulnerable and deprived social groups would take legal action for violation of their human rights within the Project time frame. Time frame: $4^{\text {th }}$ to $24^{\text {th }}$ month of the Project (February 2017 - October 2018)

4. Mobile Legal Clinic evaluation meeting and presentation of project results at the end of the $\mathbf{1}^{\text {st }}$ Project year: At the end of the first Project year, MLC organized an evaluation meeting in order to present and discuss the results achieved in the first Project year.

Time frame: 12th month of the Project (October 2017)

5. Renewal of the protocols of cooperation with local NGOs and relevant institutions, and selection of a new generation of law students to participate in the MLC project. Time frame: 13th and 14th month of the Project (November - December 2017)

6. Mobile Legal Clinic theoretical and practical training for 30 law students: the 2nd training in the 2nd Project year. Time frame: 15th month of the Project (January 2018)

7. Preparation and printing of the Mobile Legal Clinic Handbook: Having in mind the role and significance of practical training in the legal education of future lawyers, the project objectives and the potential beneficiaries of the Mobile Legal Clinic services, the project activities included the preparation and publication of the Mobile Legal Clinic 
manual (for students and wider public) which would present the most significant cases and legal problems that students encountered during the Mobile Legal Clinic service. The MLC handbook included several parts: 1) Discrimination of vulnerable groups, 2) Legal protection of vulnerable groups; 3) Mobile Legal Clinic labour standards and procedures for filing_complaints and related legal documents.

Time frame: $13^{\text {th }}$ to $24^{\text {th }}$ month of the Project (January - October 2017)

8. Final promotion of Mobile Legal Clinic project results and manual: At the end of the Project, MLC organized the final promotion and presentation of MLC project results and MLC Manual to the general and professional public. The event involved the participation of all relevant actors who took part in the Project, including partner organizations/institutions, beneficiaries, law students, local institutions and authorities, donors, local NGOs, media, etc. Time frame: $24^{\text {th }}$ month (October 2018)

9. Visibility, monitoring and evaluation activities: Different promotional activities were envisaged to be organized both online and offline to secure visibility of the project and greater impact in the local communities. Local or national newspapers, TV and radio stations were contacted to secure the project visibility. Monitoring of the project activities was performed throughout the project cycle in order to secure the implementation of the project activities in timely manner, to ensure the quality of the implementation, and to resolve unexpected problems. Monitoring was conducted by the project coordinator who visited local communities, observed MLC activities, and discussed their implementation with participants; local team also held regular weekly meetings to discuss the progress of the project.

Time frame: $1^{\text {st }}$ to $24^{\text {th }}$ month (November 2016 - October 2018)

\section{PROJECT IMPLEMENTATION AND RESULTS}

The general impression at the end of the project "Mobile Legal Clinic - service for vulnerable and disadvantaged groups" was that the project implementation exceeded all expectations. The project results prove that the project goals were accomplished in every aspect of the envisaged activities.

The overall goal of the project "Mobile Legal Clinic-service for vulnerable and disadvantaged groups" was to develop a local community service for protection of human rights of vulnerable and disadvantaged social groups. On the whole, this goal was achieved since the Mobile Legal Clinic was recognized by potential beneficiaries and all relevant institutions involved in the project. Beside this overall objective, all projected specific goals were achieved as well.

Law students were provided with the knowledge, skills and competences to protect and promote human rights; they were provided with additional educational opportunities that promoted their engagement in their local communities. As the project involved hands-on experience in working with people, the project provided students with the opportunity to discover if they would be able to work in this kind of law practice in the future, once they graduate from the Law Faculty in Niš.

On the other hand, people from vulnerable and disadvantaged groups were supported in obtaining their human rights through free legal aid and pro bono assistance, and all of the subjects engaged in the project thus contributed to combating against violation of human rights.

The project results have exceeded the expectations, which can be observed at different levels of achievement. One of the major results is that Mobile Legal Clinic was 
established and recognized at the local community as a service for the protection of human rights of vulnerable and disadvantaged social groups.

In the period of project implementation, 60 students of the Law Faculty in Niš were trained and empowered to support vulnerable groups through the knowledge, skills and competences, and enabled to protect and promote their human rights through direct engagement in the local communities. The indicator is that 60 law students admitted to the Mobile Legal Clinic participated in four MLC trainings and were actively involved in the MLC field trips in the local communities. During the MLC theoretical and practical training for 60 law students (1st training in 1st year of the project and $2^{\text {nd }}$ training in $2^{\text {nd }}$ year), students were equipped with knowledge and skills from different areas of law which they would use in the field work, and thus provided with additional educational opportunities. Indicators prove that 60 law students participated in the Mobile Legal Clinic training and that 20 professors/teaching assistants and trainers provided the basic and additional instruction in the field of human rights protection.

Besides the basic theoretical and practical training needed for the Mobile Legal Clinic purposes, the selected groups of law students students also participated in an additional training aimed at sensitizing them for the work with vulnerable and disadvantaged social groups. During $1^{\text {st }}$ and $2^{\text {nd }}$ year of the implementation of the project, a total of 60 law students received additional sensitization training in order to better understand the needs of future beneficiaries and develop not only professional relations but also empathy towards beneficiaries.

In the first year of the project, a total of 113 people reported the problem of violation of their human rights to Mobile Legal Clinic and their cases were processed. In the second year of the project, the Mobile Legal Clinic had 120 beneficiaries. During the implementation of project, legal aid was provided to 233 clients in total. Free legal aid was provided in the form of legal advice and the preparation of appropriate submissions (complaints, petitions, requests, proposals), in the areas of real, administrative, inheritance, criminal, and enforcement law. The methods of providing legal assistance to vulnerable groups were significantly improved in the course of project implementation.

A total of 233 cases were processed since the beginning of the fieldwork within the Mobile Legal Clinic, which speaks about the huge interest of clients in this form of free legal aid. It should be noted that clients recommended the Mobile Legal Clinic to others, which may be substantiated the fact that the beneficiaries stated on several occasions that they decided to contact the Mobile Legal Clinic upon recommendation of previous beneficiaries who were satisfied with the provided services. Considering the great interest among the citizens of Nis and Prokuplje, it can be concluded that the results of the project show that its primary goal to provide free legal assistance to vulnerable and disadvantaged groups in southeastern Serbia was fully achieved.

In view of exercising their human rights before relevant state institutions, the Mobile Legal Clinic teams provided legal advice and assistance to beneficiaries by writing different legal documents (complaints, petitions, requests, proposals), which the beneficiaries subsequently submitted to relevant state institutions: the Protector of Citizens (Ombudsman) of the Republic of Serbia, Police Departments in Niš and Prokuplje, the Ministry of the Interior of the Republic of Serbia, local government and municipality authorities, etc. The provided advice involved a variety of legal issues: social rights and humanitarian aid, compensation for damage, divorce and division of marital property, employment rights, debt collection, registration of claims with the privatization agency, and provision of services for obtaining personal documents. 
The Mobile Legal Clinic was also involved in the entire process of assisting a lot of Roma families, which is one of the indicators that one of the goals of Mobile Legal Clinic was fulfilled. The benefits provided to the users of the Mobile Legal Clinic are reflected in the provision of free legal aid which made the beneficiaries aware of their rights and obligations, and helped them exercise the rights which they could not otherwise exercise. The beneficiaries were provided assistance in filing submissions and requests for issuing specific documents and certificates required for the purpose of exercising certain rights, which particularly applies to displaced persons and socially sensitive groups. The provided free legal aid also had a significant educational dimension for the beneficiaries, who were enabled to understand the legal nature of the case and thus empowered to seek solution to their problems on their own, in front of relevant state authority.

In order to help citizens exercise their rights, the Mobile Legal Clinic established good cooperation with the local institutions. In Prokuplje, for example, MLC teams worked in close cooperation with the Municipal Administration, the Social Welfare Centre, the National Employment Service, the Health Centre "Toplica", the parent service, the Prokuplje police department, and the local media. The employees in these institutions often referred the MLC beneficiaries to the Municipal Centre for advice on further procedures, legal forms and requirements that had to be fulfilled. Information on the work of the Mobile Legal Clinic was available to the citizens of the Toplica District. The local coordinator collected information on employment, health care, child allowances, taxes, loans and subsidies for farmers in relevant local institutions. The Mobile Legal Clinic working plan was drafted and its implementation was closely observed according to the plan.

In order to receive feedback on the protection and exercise of the rights of the MLC beneficiaries, the Mobile Legal Clinic staff was in contact with the beneficiaries after the provided free legal assistance. In this way, the Mobile Legal Clinic obtained information on further developments in the specific case, the commitment of state institutions to resolve disputable issues, the treatment of beneficiaries in institutional proceedings, and the actual extent of exercising their rights. The users' feedback on the services provided by the Mobile Legal Clinic is positive in $90 \%$ of the cases. The beneficiaries were satisfied because, as they noted, they previously had not had the opportunity to get the necessary information and assistance in one place.

\section{SOME EXAMPLES OF SUCCESSFUlly RESOlVED CASES}

In order to illustrate the results of the Mobile Legal Clinic activities, we provide some examples of successfully resolved cases.

In M.E. case, free legal aid was provided to a legally invisible person. She had previously addressed various departments, but state authorities had no understanding for her problem. She lived in Germany as an asylum seeker, where she was born. However, she gave inaccurate information about her name and surname in Germany, as she thought that her surname was Djukatani. As a result, her daughter was entered into different registries in Germany under the wrong name, and thus could not be entered into the birth register in Serbia. As she was a legal invisible person, the mother could not exercise any right for her daughter, including the right to health care and financial social assistance. The Mobile Legal Clinic team helped her collect the necessary documents and initiated the procedure before the Ministry of Foreign Affairs, which was soon resolved favourably. 
A.J. from Prokuplje was a victim of domestic violence who contacted the Mobile Legal Clinic because she did not have money to hire a lawyer. Her ex-husband separated her from her child (aged 2) and did not allow her to contact her child. The Mobile Legal Clinic drafted her petition for divorce and helped her file a lawsuit for divorce and a request of child custody. The Mobile Legal Clinic also prepared a private complaint for domestic violence. When the court instituted legal proceedings, the Mobile Legal Clinic provided legal advice to A.J. before each court hearing. In all judicial proceedings, the courts ruled in favor of A.J., who was granted child custody and awarded alimony to be paid by the former husband, who was also order to pay compensatory damages for the physical injury she sustained as a victim of domestic violence.

In the case of M.M., a single father from Prokuplje, who is unemployed, the provided legal assistance was related to child custody of a one-year old infant who was placed in care of the center for abandoned children (Center for the protection of infants, children and youth) in Belgrade. His unmarried wife took the child with her to Belgrade. She was a registered drug addict. After the Center for Social Work in Belgrade found that she had neglected her child, the infant was taken away from her and placed in care of the center for abandoned children in Zvecanska, Belgrade. M.M. did not know the wherabouts of the child, nor did he know how to solve this complicated situation. The Mobile Legal Clinic informed the Social Welfare Center in Prokuplje, which forwarded his request and personal data to the Social Welfare Center for in Belgrade. The Mobile Legal Clinic helped M.M. file a lawsuit for the child to be entrusted to his care. The competent court ruled in his favour. At the same time, the Mobile Legal Clinic helped him exercise the right to financial support and child allowance.

\section{The Aftermath of Mobile Legal Clinic SERVices}

The Mobile Legal Clinic Handbook was developed and published in 2017, and 100 copies were distributed to all relevant subjects involved in the project. Local communities in Nis and Prokuplje are well aware of the need for protecting and promoting human rights, and how Mobile Legal Clinic at the Law Faculty in Niš contributes to this idea, particularly considering the wide range of legal issues covered in the course of providing free legal aid within the project. The information about the Mobile Legal Clinic activities was disseminated in more 20 promotional presentations and more than 20 interviews for different media. As a result of these activities, the local communities have started creating a new network of organizations and institutions for the support of vulnerable and disadvantaged social groups.

During the project implementation activities, specifically in the fieldwork, many institutions and organizations learned about the Mobile Legal Clinic for the first time and expressed interest to cooperate with Club for Youth Empowerment 018 (KOM 018) and the Faculty of Law in Niš. For this reason, recognizing the need for including members of vulnerable groups from other local communities, Club for Youth Empowerment 018 expanded the work in the field by establishing cooperation with the Roma organization "Sa e Roma" from Vlasotince, whose members received free legal advice and assistance on the premises of KOM 018 in Nis.

Proofreading and copy-editing:

Gordana Ignjatovic 